\title{
The Insan Kamil of Bawa: The Metaphysics of a Tamil Sufi Sheikh
}

\begin{abstract}
Al-insan al-kamal or insan kamil is commonly translated as the perfect being, the servant, the universal man, or the perfected being in Islamic mysticism (Buckhardt 1959, 1979; Izutsu 1983; Baldick 1989; Schimmel 1992; Chittick 2000, 2005; Dagli 2004). In this doctrine, the human being is positioned as the isthmus between Allah (God) and the cosmos. A mirror that reflects tawhid (unity) (Chittick 2000) and the barzakh (interface) between God and the world, an insan kamil is the perfected being who preserves the existence of the universe (Baldick 1989). The Tamil Sufi Sheikh Muhammad Raheem Bawa Muhaiyaddeen (d. 1986) reformulated the doctrine of insan kamil when he taught his followers in Sri Lanka, United States and Canada. Bawa, as his adherents referred to him, was a teacher of Sufi-Islam from Sri Lanka who migrated to Philadelphia in the 1970s. The paper explores the paradigm of insan kamil as taught by Bawa, while situating this figure of the insan kamil within classical Sufi thought. The primary goal of this paper is to explore Bawa's metaphysical understanding of the human being through themes of the insan kamil as al-qutb (spiritual mediator), the perfect being and the qalb (heart).
\end{abstract}

Keywords: Bawa Muhaiyaddeen, Bawa Muhaiyaddeen Fellowship, Sufism in North America, Insan Kamil, Perfected being, Sufism, Metaphysics 


\section{Introduction $^{1}$}

There was once a powerful king who was childless. In the hope of gaining mercy from God, he promised to perform rituals for twelve years so that God would bless him with a child. He built temples, churches and mosques and performed prayers in each sacred space. In the twelfth year of service the king went to the festival at Murukan temple. ${ }^{2}$ On the eve of the festival, the king had a "vision" which directed him to a shrine to find a baby on the steps (Muhaiyaddeen 2003). On the day of the festival the king and a hired driver were walking to the shrine when they found a hideous and sickly baby on the steps. The king was disgusted and walked past it but the driver was sympathetic and picked him up. The king reprimanded the driver and demanded that he leave the baby but the driver refused. Fired from his position, the driver walked back to his meagre home to his wife and two children, but as he walked the baby began to regain life, beauty and health. Time passed and the king decided to summon his driver to return to his job. When the driver appeared at the king's abode with the baby from the temple, the king fell in love "with the light radiating" from the baby's face (Muhaiyaddeen 2003). The king asked for the child but the driver did not want to give him up. Agreeing to share the responsibility of the baby, the driver and his family moved to the king's palace with the child so they could be with the child. It was in this manner that Muhammad Raheem Bawa Muhaiyaddeen, (d. 1986) the Tamil Sufi teacher began his life of a prince with worldly wealth which he would later deny to become an insan kamil, or the perfected being.

Tales of Bawa, as his disciples referred to him, follow the framework of classical hagiographies, a common stylistic tradition used amongst religious communities to relay the narratives of saints. Bawa's hagiographies make reference to a king who miraculously found a baby in Murukan temple and became a prince entitled to a kingdom but abandoned all wealth and fortune to seek wisdom. After his own long and spiritual journey, Bawa opened an ashram (house) and started a farm in Jaffna where individuals from various faith communities from across the island of Sri Lanka came and asked him for personal advice. ${ }^{3}$ In time his fame spread beyond Sri Lanka by way of a Sri Lankan graduate student in the United States whose contacts invited Bawa to Philadelphia, Pennsylvania, and created the Bawa Muhaiyaddeen Fellowship (BMF). ${ }^{4}$ Bawa's charisma attracted individuals from the anti-institutional movements of the counter-cultural era especially the spiritual seekers of the baby-boom generation (Wuthnow 1998). He also maintained ties with his 'followers', or children as they were known, in Colombo, Jaffna and Kayts, Sri Lanka, creating a community through his uniquely transnational presence as a living saintly teacher. Prior to his death, Bawa requested to be buried in Chester County, just outside Philadelphia, where his mazar

\footnotetext{
${ }^{1}$ I would like to thank Meena Sharify-Funk and William Rory Dickson for reading earlier drafts of this paper and for the reviewers' helpful comments, though any mistakes are solely my own.

2 In Sri Lankan Tamil Hindu poems, such as puram, the quality of maram (courage in warfare) is associated with the deity of Murukan and is most revered though temples dedicated to Saiva are common in Sri Lanka it is Murukan and his heroism that is most traditionally venerated in Sri Lankan Hinduism. So it is important to note this to understanding the value of Bawa being found at Murukan temple as a baby, for more see Jacobsen, Knut 2011.

${ }^{3}$ Between 1940-42 two Tamil Hindu brothers saw Bawa near Kataragama (Korom 2012b, 225) and soon thereafter, he lived with the brother's family and "ministered" to visitors in Jaffna. In 1952 he "acquired a former Dutch warehouse, opened an ashram" and started to grow a farm on the land to feed his many visitors. It was during this phase he became known for his healings, exorcisms and spiritual teachings. Word of his fame and wisdom reached the capital city of Colombo and attracted elite Muslim "intellectuals and Theosophists" which led to the formation of the Serendib Sufi Study Circle in 1962 (Ibid.). Religious studies scholar and anthropologist Frank Korom (2012, 2012b, 2011) has written on Bawa's early life and the development of the different movements surrounding Bawa's teachings, so I will avoid repeating him here, for more on Bawa's early life please see Korom.

${ }^{4}$ In New Orleans an American woman Carolyn (Amin) had a peculiar "mystical" experience (quoted in Narayan and Sawhney 181). She struggled with this occurrence for five years until 1968 when she encountered a Sri Lankan graduate student who spoke of meeting Bawa in Sri Lanka (Korom 2012b, 229-231). She wrote letters to Bawa and encouraged him to visit America (Ibid.). In order to facilitate a visit to Philadelphia, she gathered other seekers and created the Bawa Muhaiyaddeen Fellowship (BMF) to sponsor the visitor's visa for Bawa's arrival to the United States on October 11, 1971(Ibid. 230).
} 
(burial shrine) now flourishes as a site of pilgrimage for many Sufis and Muslims in North America (Ghanea Bassiri 2010; Ernst 1997). ${ }^{5}$

Scholars in the field of religious studies, contemporary North American Sufi studies and anthropology have called attention to this mystical figure from the East and the presence of his followers in Philadelphia (Mauroof 1975; Hermansen 2000, 2006; Webb 1994, 1998, 2006; Korom 2012, 2012b, 2011; Dickson 2012). Professor of Religious Studies at Seton Hall University Gisela Webb $(1994,1998,2006)$ is one of the first to conceptualize the development of Sufism in North America according to three waves or trajectories. Webb highlights Bawa's significance as she located Bawa's migration to Philadelphia in the second-wave of Sufism ${ }^{6}$ and explored Bawa's teachings through three paintings by Bawa in her contribution to John Renard's edition in Windows on the House of Islam. ${ }^{7}$ Most recently, Professor of Anthropology and Religion at Boston University Frank Korom $(2012,2012 b, 2011)$ has been exploring the development and history of Bawa and the Fellowship. Focusing on Bawa in Jaffna and Colombo, Korom's archival work has been valuable as he was the first to call attention to Bawa's life in Sri Lanka. Korom emphasizes that Bawa was a "non-literate Tamil-speaking zindah pir (living saint)" affiliated loosely with the South Asian Qadiri Sufi Order (2012b, 34). 8 These studies have contributed to the growing canopy of research focused on the Fellowship and more generally on Sufism in North America. As Bawa and his Fellowship continue to gain attention in different fields of Sufism, such as engaged Sufism (Kugle and Shaikh 2006), Sufism and sustainable agriculture (Finnegan 2011) and Peace Studies (Said and Funk 2001), there remains a considerable silence in scholarship on his actual discourses ${ }^{9}$, which stress matters of metaphysics and cosmology. The study of cosmology relates to the genesis of the cosmos, the universe and humanity's relationship to it, or more simply the why, how and what of creation, while metaphysics can be understood as the discursive traditions by theologians, philosophers and mystics on matters of the cosmos, divine beings, humanity and more. Exploring such teachings of Bawa can serve well to explicate Bawa's own relationship to Sufism and Islam, but more significantly such an enterprise can help scholars begin to grasp the appeal of both Bawa and his teachings to his multi-religious and ethnically diverse followers. It is precisely to comprehend the phenomenon that is Bawa's varied devotees, or what they self-identify as "Bawa's funny family" that I began to study his discourses and sought answers to questions such as what are Bawa's teachings? What does he say about cosmological relationships of the human being to creation and Allah? Where

\footnotetext{
${ }^{5}$ Korom $(2012,2012 b, 2011)$ engages with many stories of Bawa's initial followers who were drawn to this charismatic figure from the East. Many conversion stories relate accounts; such as leaving school and quitting jobs just so his followers could be with Bawa in every waking moment. Some even claimed that they devoted their time to him "mostly out of a lingering concern that not being present even for one minute might lead to missing an utterance of wisdom (jñānam) emanating from his lips" while another woman stated "we desired only to be in his presence. There was no desire to go out or to do anything else" (Korom 2012b, 11). During this time, prominent individuals like Michael Green, artist and designer, and Coleman Barks, poet and professor, encountered Bawa. It is said that Bawa encouraged Barks to translate Jalal al-Din Rumi's (d.1273) poetry into English, adding influence to the "Rumi-phenomenon" in North America.

${ }^{6}$ The first wave dating back to the early 1900s was solidified as links between Euro-American and Asian worlds attracted teachers, such as Hazrat Inayat Khan (d. 1927), to travel to America and found orders, such as the Sufi Order International. The counter-cultural movements in the United States that resulted in the revival of Eastern mystical traditions, including Sufism, amongst spiritual seekers, sparked the second-wave such as by Bawa and the Fellowship. The third and current wave in America is one that based on the institutionalisation of Sufi orders, such as the Bawa Muhaiyaddeen Fellowship, but also includes the new flow of immigrants from majority Islamic communities and the creation of transplant communities (Webb 2006).

7 Webb explores three of Bawa's paintings: the Four Steps to Pure Iman, the Inner Heart and the Rocky Mountain of the Heart, to understand Bawa's teachings (1998, 291-295).

${ }^{8}$ Korom (2012b) has suggested that it is likely that Bawa was from South India and travelled to Northern Sri Lanka. This claim of Bawa's origins in India is supported by his connection to the Qadiri Sufi Order, with a popular presence in South Asia. This order developed from the teachings of Abdul Qadir Jilani (D. 1166), known popularly as the "Saint of Baghdad" and is part of most prominent Sufi silsila (lineage).

${ }^{9}$ The Fellowship refers to the oral teachings, which are all video or audio-recorded and used to produce the written books, as discourses and I employ the term discourses in the same manner here.
} 
does the individual fit in the larger scheme of the cosmos? How does Bawa's teachings on cosmology and metaphysics relate to classical Sufi theologians and mystics? And for scholars, how can Bawa's metaphysical teachings add nuance to discussions of Sufism and Peace Studies, engaged social activism or environmental sustainability?

There are several reasons for the above gap in literature on Bawa's discourses. First, and I think most importantly, it is an issue of language as all of Bawa's recorded oral discourses are in Tamil. ${ }^{10}$ Bawa also layered languages using Qur'anic Arabic, synthesizing it with Tamil, along with the occasional use of Sanskrit and English words and phrases. ${ }^{11}$ For this reason, from the initial days of the Fellowship, interpreters were used to translate his teachings into English. The first interpreters were also native Tamil speakers, but as the Fellowship grew some non-Tamil speaking followers began to learn Tamil so that they could communicate with Bawa without a mediator. It is surely due to the use of multiple languages and references to different cultural and religious traditions that make the ta'wil (the inner interpretations) of Bawa unique, multilayered and even convoluted at times. Language aside, Bawa's discourses also took place over hours and manifested in sporadic forms of songs, stories, question and answer sessions and lectures. They explored themes of mystical numerologies, esotericisms of letters, sacred grammar, cosmologies, elemental natures (earth, fire, water and air), angelology, prophetology, Qur'anic and hadith traditions (i.e., stories of Musa and Khidr), and referenced Hinduism (in which he emphasized aspects of maya, or illusion), Zoroastrianism and Christianity. ${ }^{12}$

My focus for this article is the subject of insan kamil using the English translations on Bawa's recorded teachings. I also supplemented these readings by listening to two discourses given by Bawa specifically on the topic of insan kamil. The first was a talk entitled Change to Insan Kamil the Direct Connection given on March 31, 1979 and the second was a song sung on May 27, 1978 called Come Together and Search for God. I listened to the original recordings in Tamil and compared my own translations to those of the original translators, which accompany all recorded discourses of Bawa. ${ }^{13}$ As a comparative analysis of the written and oral discourses of Bawa in Tamil, through the interrogation of specific syntactical religious and cultural themes within a more broader Sufi hermeneutical milieu the following paper explores the paradigm of insan kamil, or the perfected being, as expressed by Bawa. The study theoretically situates the concept of insan kamil within classical Sufi thought but aims primarily to explore Bawa's philosophies, metaphysics and world-views as a means to begin to understand both Bawa and his Fellowship in North America and Sri Lanka; the latter of which is the basis of my doctoral research and so is beyond the scope of this introductory paper.

For Bawa, insan kamil, or the perfect being, is an individual who has realized their inner essence as that of Allah. Insan is defined as a "true human being" and a manifestation of "Allah's qualities, actions, conduct, behaviour, and virtues" (Muhaiyaddeen 1979: 194). The

\footnotetext{
${ }^{10}$ For the sake of consistently I will use the transliteration of Tamil and Arabic when using direct quotes and maintain gender exclusive "man" or "he" as found in the published books by the Fellowship Press, but when not quoting directly I will use the standard Arabic and Tamil transliteration and gender inclusive terminologies. I will also include (T) following Tamil terms to distinguish them from Arabic terms throughout the discussion to help readers.

${ }^{11}$ Bawa's teachings on cosmologies maintain multiple layers of meanings, both within the tradition of Islam and Hinduism and also within various linguistic traditions of Tamil, Arabic and Sanskrit. For instance, Bawa discusses nur (light) as an important state of being and quality of Allah in Islamic theological understanding. In Tamil, nuru is the number for one hundred and Bawa develops it thematically as a whole, perfected number and a state of being using both the Arabic-Islamic understanding of nur and Tamil understanding of nuru.

12 Bawa parallels the four religions Hinduism (Zaboor), Zoroastrianism (Zabrat), Christianity (Injeel) and Islam (Furgan) with the four steps of Sufi spiritual development commonly known as shari'at (law), tariqat (path), haqigat (truth) and ma'rifat (gnosis or realization of God) and the Tamil equivalent of methods of worship including sariyai (devotion and service) kiriyai (ritual both internal and external), yogam (inward) and gnanam (wisdom) (Muhaiyaddeen 1976).

${ }^{13}$ Integral to the completion of this chapter as well as my doctoral dissertation, was Imam Muhammad 'Abdur-Razzaq, of the Fellowship mosque in Philadelphia, who was kind enough to send me the audio files of Bawa's discourses in Tamil.
} 
insan kamil is the "perfected, God-realized being" who is oriented towards the "wealth" of Allah and has abandoned worldly wealth that is driven by the mind. He is the being who has "acquired God's qualities, performs his actions accordingly and contains himself within those qualities" (Muhaiyaddeen 2006: 9). This state is the highest state that a human being can achieve, as it is a state that signifies unity with God. It is for this reason that Bawa referred to the insan kamil as God-Man, Sun-God, Light of God and Son of God (Muhaiyadden 2006: 9). The French Islamicist Henry Corbin and the Islamic scholar Shah Waliuallah of Delhi often orient their study to the medieval Sufi 'Abd Al-Karim Jili's (d.1403) the Book of the Perfect Man (Kitab al-Insan al-Kamil) when discussing the doctrine of alinsan al-kamil or the pure being. ${ }^{14}$ According to al-Jili, the human being is a "cosmic thought" whose universal spirit goes through a process of descent into matter and ascent out of matter (quoted in Waliuallah 34-35). This journey of the pure being, al-Jili writes, is contained in three stages: adhiya (oneness), huwiya (he-ness), and aniya (I-ness) (quoted in Waliuallah 34-35). Al-insan al-kamil is also translated as the perfect human or servant, the universal being, or the perfected being. ${ }^{15}$ Annemarie Schimmel expresses it theologically as the "meaning and end of creation" (1992: 34). William Chittick's description goes further and explains that human beings have two perfections. The first is natural and results in physical death, resurrection, and the union with God, and the second is only attained through the "voluntary cultivation of the soul" (2000: 86). The first marks life stages of growth and death, while the latter results from one's free will to determine the form of existence that manifests in between the physical process of growth and death. Sufis call those on this path of voluntary cultivation of the soul as being on the path to God or a path of return to the "true human status" as the insan kamil (2000: 82).

The trajectory of the development of insan kamil from al-jili to Bawa is not the primary aim of this paper but attention does need to be drawn to the issue of insan kamil in discussions of classical Sufi thought and how Bawa's own discourses on insan kamil illuminate similar themes albeit in different cultural and historical contexts. For the sake of a cogent analysis, I will focus on three interrelated categories in my discussion of insan kamil. I will begin with the insan as the spiritual mediator, al-qutb (pole) or logos (divine word) (Arberry 1950; Nicholson 1963) and then move to explain it as the highest state of being among ordinary human beings. It is here that the barzakh (isthmus), which provides human beings with the unique disposition of "ontological comprehensiveness" (Izutsu 247) or the recollection of Allah's zat (essence) presents the possibility of tawhid (unity of oneness), which can only be known through the spiritual organ of al-qalb (heart) the topic of my last category of analysis.

\section{Insan Kamil as al-Qutb or the Spiritual Mediator}

In the teachings of Bawa, the nabi (prophet) represents the manner in which any human being can achieve the state of unity with the divine and become the universal prototype, the perfect being or the insan kamil. Throughout Bawa's spiritual teachings he recalls the holy figures of the Abrahamic traditions as exemplars for humanity in their own path to God. In relaying stories of prophets such as Musa (Moses), Isa (Jesus) or Muhammad, Bawa used these spiritual figures as models for the journey of the insan to become insan kamil. He also incorporated multiple layers of understanding to his renditions of stories of the prophets. His retelling of the story of Khidhr [sic] nabi and Musa in the Guidebook (1976: 37-57) is such an example. ${ }^{16}$ Bawa understands Khidr as the "Prophet of Life existing eternally as Wisdom, the fifth level of consciousness within man" who exists within every true human being (1976: 37).

\footnotetext{
${ }^{14} \mathrm{Al}-\mathrm{Jili}$ was a medieval Sufi theologian, philosopher, poet and mystic born in present day Iraq in 1365 and is known mostly for his formulations of al-insan al-kamil. For more, see 'Abd al-Karim al-Jili, by Lo Polito, Nicolas.

15 See Buckhardt $(1959,1979)$ Izutsu (1983), Baldick (1992), Schimmel (1992), Chittick (2000, 2005), Dagli (2004).

${ }^{16} \mathrm{Al}-\mathrm{Khidr}$ is considered the perennial guide and mystic in Sufi tradition and the encounter between Khidr and Musa in the Qur'an in the $18^{\text {th }}$ sura ("the Cave") is the model of spiritual guidance. For more see Halman, 2013.
} 
Bawa explained that Khidr attained his state through penance, purification and meditations. Archangel Gabriel taught and guided Khidr to the "True Guru" or God, showing the inner meaning of actions (i.e., stealing gold, killing of a man, a child and people in a boat) to Khidr (1976: 41-57), instead of Khidr to Musa as it appears in the Qur'an; “And he [Musa] found a servant from among our Servants. We gave him mercy from Us. And We taught him knowledge from Our presence" (18:65).

Bawa uses these prophetic figures to stress that these individuals have bonded with Allah because of their beauty of their qulub (hearts), a state of beauty that always has been accessible to humanity but that has been lost in the recent age of earthly desires (Muhaiyaddeen 1979). Bawa explains that the soul must return to the state of Adam and Eve as the first mother and father and to the four archangels, Mikael, Jibril, Israfril and Izraeel (1979). The latter is dependent on the understanding of the Names of Allah, for in knowing the names one arrives at the state of the perfected being. ${ }^{17}$ Bawa explains, "it is good to merge into that One from where you came. The body that came from God has to merge and disappear within God Himself. That which is within is the True Form of Man" (1979: 211). Once you achieve this state "you will be the prophets, you will be the representatives of God, you will be the saints of God, auliya" (2006: 143). Upon reaching this state "you will not need any other driver. Whatever skill you need will be available. You can drive, you can go, you can get off, you can do anything you want" (2006: 143). Once you achieve this state he says, "you will be the prophets, you will be the representatives of God, you will be the saints of God, auliya" (2006: 143).

According to Toshihiko Izutsu's seminal commentary, Sufism and Taoism, Ibn 'Arabi (d. 1240) imagined the human being on two levels, first is the cosmic level. ${ }^{18}$ On this level, the human being "is the most perfect of all beings of the world for he is the Imago Dei" (image of God) and so "man is the Perfect Man" (218). On the second level, the human being is an imperfect individual. Titus Burkhardt explains that the universal being can also espouse two meanings: the universal being denoted beings who were spiritual mediators such as the prophets Adam and Muhammad, the poles (pl. aqtaab) ${ }^{19}$ among the saints, and a "permanent and actual synthesis of all states of being" accessible to all beings (1976: 77). Buckhardt expresses this prototype of the human as the perfect Adam while Jalal al-Din Rumi referred to it as the "Adam-related" or adami, the highest state of spiritual perfection. ${ }^{20}$ Ibn "Arabi writes, "Adam emerged in the form of the name God, because this name contains all the divine names. Human beings, though small in body, contain all meanings" (quoted in Chittick 2000, 82). Abu Hamid Muhammad ibn Muhammad al-Ghazali the twelfth century philosopher, theologian, jurist and mystic, expresses that Adam is the ideal of human perfection:

God showed beneficence to Adam. He gave him an abridged form that brings together every sort of thing found in the cosmos. It is as if Adam is everything in the cosmos or an abridged transcription of the world (quoted in Chittick 2000: 82).

\footnotetext{
${ }^{17}$ In Islamic theology Allah is said to have revealed ninety-nine names or qualities in the Qur'an and these names include al-wadud (the loving one), al-hafiz (the preserver) and al-shakur (the rewarder of thankfulness)- yet the greatest name is Allah.

${ }_{18}$ Muhyi al-din ibn al-Arabi (d. 1240), born in Murcia, Spain, was a prominent Sufi mystic and writer and is given the title "the greatest shaykh" (al-shaykh al-akbar) and has influenced Sufi thought and philosophy, especially of his understanding of wahdat al-wujud (oneness of being).

${ }^{19} \mathrm{Al}-\mathrm{Qutb}$ is translated as the pole or axis of the universe. It signifies an individual who has attained an inner gnosis that is completed through outward manifestation of 'radiance' that attracts followers. In Sufism it could be understood as the Pole of a Spiritual hierarchy or can refer to an era i.e., the pole of a period for more see Buckhardt, 1959.

${ }^{20}$ Mawlana Jalal al-Din Rumi (d.1273) was born in Balkh where he encountered many Sufi teachers but it was the dervish Shams-i-Tabrizi who changed his life and it was their relationship that inspired him to write poetry, which led to the foundation of the Mawlawi order in Konya, Turkey.
} 
Prophet Muhammad, in contrast, is signified as the "prototype of the prototype" or logos (divine word), the true qutb (pole) (Arberry 1950: 93). In her cosmological and metaphysical study Sufi Expressions of the Mystic Quest, Laleh Bakhtiar explains "unity of being" through the primal tenet of the Sufi expression "there is no god but God" (La ilaha illa'Llah) and "Muhammad is the Prophet of God" (Muhammad rasula' Llah) (9). The first, she writes, "expresses the concept of the Unity of Being which annihilates all multiplicity, all separate entities... [while the second tenet] expresses the concept of the Universal Prototype (most often translated as the Universal Man)" (9) underlining both unity in multiplicity and multiplicity in unity. In Bawa's teachings Prophet Muhammad embodies nur (light) from prior to primordial creation, which set this prophetic figure above others. The manifestation of first nur is Muhammad Mustafa- the rasul (messenger) whose primal existence is what defines his role as the seal of the prophets..$^{21}$ It is for this reason that Bawa repeatedly speaks of the idea of aham (heart) (T) and muham (face) (T) as qualities that when realized together signify Muhammad- the ultimate form of manifestation of the Nur (Allah). In the end, it is Bawa who referred to himself as the "ant-man" (1976: 186), alluding to his physical size, strength and power, which in spite of remains the qutb (pole) for his followers.

\section{Insan Kamil as the Perfect Being}

In Bawa's teachings, humans are made up of two sections the zahir (outer) and the batin (inner). The outside form, or body, is often referred to as the shirt (body) and represents damaging qualities of arrogance, karma and maya (illusions) that must be overcome. The shirt contains "four fangs" with "seven kinds of poisons" or shaktis (energies) and can be signified by the four elements of earth, water, air and fire. Associated with arrogance, karma, maya and Satan 22 these four elements are also part of what Bawa refers to as the nine precious stones: earth, fire, water, air, ether, mind, desire, wisdom and the soul. Bawa elaborates: of these nine precious stones "wisdom is the gem, the soul is the light, and the rest are the body" (1979: 5). The body and the qualities associated with it must be transcended and humanity's purpose is to "return to [their] original state of beauty" (Ibid.). Bawa teaches that the goal of the human being is to search within him or herself. It is only by returning to one's primordial state in which all illusions, or nafs (lower base desires), are destroyed that one can perform the duty set by Allah, Andavan (T) or God (1979: 11). The self consists of seven qualities of the body - falsehood, murder, theft, sex, intoxicants, miserliness and envy - and seven qualities of the mind including egoism, attachment, anger, lust, maya, karma and arrogance (1979: 113). It is upon transcending these negative qualities of the body and mind that the insan becomes the insan kamil.

In Sufi theology, the potential to progress through these states of being is granted to all people but transcendence to higher realms of states depends on ontological comprehensiveness. Izutsu explains, "all men are naturally endowed with the same

\footnotetext{
21 The Resonance of Allah: the Resplendent Nur Arising from the Grace of Allah (2001) was a text dictated by Bawa to another non-literate disciple in Sri Lanka in Tamil in the early 1950s. This text seems to be the penultimate commentary of Bawa's philosophies and theologies. In this text Bawa explains that Allah was himself in "torpor" before time and from this statelessness and beginningless beginning or anathi $(\mathrm{T})$ was the manifestation of the first primordial nur (light) which was Nur Muhammad. Fariduddin Attar of Nishapur (d.1220) known for his hagiographies of Sufi saints and his seminal flight narrative of the Conference of the Birds understands this primordial manifestation of Nur Muhammad as the Haqqia Muhammad, or the Muhammadan Reality- a reality that makes Muhammad the primordial creation which endows him with the role and status as the seal of the prophets.

22 These elements itself represent various qualities and are associated with particular angelic or prophetic beings within the Abrahamic and Hindu traditions. Earth, which contains four hundred trillion ten thousand poisons is often represented with Adam and Eve (Paravadi) (T) and Hawwa. Water is connected with the devi or spirit Gangadevi or the archangel Mikael and contains one thousand and eight poisonous forces. Air is connected to the spirit Vayubagavan or the archangel Izrafil and contains two thousand one hundred and twenty eight poisonous forces or energies. Finally, fire is associated with the spirit of Akkinibagavan or Izraeel, the archangel of death, and contains one thousand and eight poisonous forces that include jinns (spirits), fairies and Satan as well as arrogance, egoism, pride and jealousy (Muhaiyaddeen 1976).
} 
ontological 'comprehensiveness' but not all men are equally conscious of the 'comprehensiveness' in themselves" (247). Comprehensiveness refers to the "highest" state of clarity of the "Divine Consciousness of the Names and Attributes" of Allah (247). This state of Divine self-consciousness can be developed from the remembrance of God's Names. Chittick refers to this ability to comprehend the Names of God and its corresponding essence (zat) as the "distinguishing feature of man" (2005: 62). ${ }^{23}$ To remember the true reality of the existence of the human being is to know that "God cannot be understood apart from the object that it reflects" (Chittick 2000: 8). This process of actualizing and remembering the human potential for perfection requires the assistance of God and the exemplars who have achieved this perfection such as the prophets and the saints. The perfected being retains his/her outward form of "human individuality" but all forms and states are reliant on an inward reality (Burkhardt 1976: 77) or balancing of the inner and outer domains of the human. This results in the return to the state of perfection of the primordial soul (Lings 1975). The above process is reflected in Bawa's teachings to his disciples. According to his instruction, the way to achieve this state of insan kamil is via a process of analysis, filtering, separation and re-filtering. Bawa also refers to this process as a "beautifying" processbeautifying one's inner self by which one merges with Allah $(1978,1979)$. He adds that one must analyze the worlds that exist within the body, the beasts that exists within the body, various animal qualities, such as arrogance and desires, and separate them from the elements (earth, water, air and fire) and filter them from illusion (1976). The purpose of this analysis and filtration process is to determine their various uses after which "man can use these as instruments throughout the universe" (1976: 102). The last process of re-filtering, or wiping the mirror of the soul, constitutes "man's most important duty" (dharma) and requires man "filter and re-filter himself so that he may discover himself" (1976: 103). When the steps of research and analysis are complete, the human being within him/herself climbs through seven layers of wisdom, in the following ascending order:

1. Perception

2. Awareness

3. Intellect

4. Assessment

5. Wisdom

6. Divine Analytic Wisdom (Pahuth-Arivu) (T)

7. Divine Luminous Wisdom (Per-Arivu) (T)

The analysis, or research, leads to three truths: the Son, Wisdom and God (2006: 135).24 The acquiring of wisdom is the ability to transcend illusions of the body and mind. Similar to ontological comprehensiveness, or the state of fully understanding the Divine Consciousness and qualities of Allah, is the state that Bawa refers to as Pahuth-Arivu (T), Divine Wisdom and Divine Analytic Wisdom. This arivu (T) (wisdom) is the knowledge that explains and

\footnotetext{
${ }^{23}$ The act of remembrance involves the recitation of the names of God. As an exercise of "transformation" it allows no time or space for the contemplation of anything but Allah. This practice illuminates the importance of "awareness" as a crucial step in perfecting, purifying and cultivating the human (Chittick 2000:16). Carl Ernst suggests that "there is nothing of greater significance than the names used to describe God" through the performance of zikr (remembrance) (1997: 81,88).

${ }^{24}$ This triplicity is numerologically important in Sufism as Bakhtair explains: "three is conceived of as the level of singleness" in which the first is the "absolute 'with knowledge,'" the second is "being 'with knowledge,'" and the third is the "knower and known (a subject, a motion and an object)" (13). She continues to explain "creation begins with the One at the point when it has singleness. This singleness has another three aspects that participate in the process of creation. First, there arises Knowledge of the Self within the One as It moves towards manifestation. At this moment, the Archetypes (a'yan thabitah) or Divine Names and Qualities appear in Divine Consciousness. This marks the birth of multiplicity. Essence, or the Hidden Treasure, moves to the level of the Divinity. Subsequently, Will arises to bring the Archetypes from non-existence (phenomenally) to phenomenal existence. On the basis of the Divine Will, the Command "Be!" is issued and the universe is created" (13).
} 
"measures the length and breadth of the seven oceans of the nafs [or desires and]...awakens all the truths which have been destroyed and buried in the ocean of maya [illusion];" and it also leads to true iman [faith]" (1979: 201). It is "that which explains the state of purity to the hayat [life] in the same way that it existed in awwal [the beginning of creation]. The grace of $z a t$ [the essence of God], which gives the hayat of purity back and which makes it into the divine vibration" (1979: 201). ${ }^{25}$ Insan kamil is the realization of God within the human being as well as the essence of all other beings and creation. The analysis and research is the meditation of God as truth and light (nur) leads to the Divine Luminous Wisdom as the human being not only remembers (ninivu) (T) his/her essence (zat) but he/she also achieves fana (self-annihilation) from desires (nafs) or asai (T). For Bawa, Divine Analytic Wisdom is associated with nur, the pure light, and is the state of God's shanti, a state of peacefulness. In this state the human being conquers "his birth and the three aspects of awwal [creation], dunya [this world], and akhir [the hereafter]" (1976: 211). ${ }^{26}$ The dominance of these three sections (the creation, this world, and the hereafter) is needed to "understand ... the One who is the Leader of this State" (1976: 211).

When one reaches this state of being, one transcends states of jabarut (the sphere of divine knowledge) and malakut (the sphere of angels where human being's heart is angelic) and dwells in the lahut (the state of oneness or complete union with God) or taqwa (Godconsciousness). ${ }^{27}$ This state of tawhid (oneness) is dependent on the realization of the Divine Qualities and Names of God within oneself because the world is inside the human being. As Bawa explains, "God is in you ... Heaven is inside of you, and hell is inside of you. Everything is inside of you. Open yourself and look a little" (1978: 118). For Bawa, the body of the human being contains eighteen thousand universes of all existence of creation, even in the single atom. The recognition of the Divine Qualities and Names of God plays a crucial role for Bawa, and it is for this reason that Bawa encouraged this form of zikr (remembrance) of the Asma'ul-Husna of Allah, or the ninety-nine Holy Names of God ${ }^{28}$ because it is by remembering and meditating on the qualities of the Divine Names of Allah that one is remembering oneself. This understanding is led by the qalb (heart) that must direct itself to the world of the arwah (soul) by "destroying the base desires [nafs]" (Muhaiyaddeen 1979: 109).

\section{Al-Qalb or the Inner Vision of the Heart}

The qalb, according to Sufis such as the Persian mystic and martyr Mansur al-Hallaj (d. 922), is the essential aspect of the human being. "It is a movement within a lump of flesh placed in this central part of man... [and] a permanent and incommunicable pulsation, a hidden spring of gesture;" it is the secret and hidden place (sirr) of the conscience whose najwa (secrets) will be revealed on Judgment day (quoted in Massignon 12). Reynold Nicholson in the Mystics of Islam calls attention to three organs of "spiritual communication:

\footnotetext{
${ }^{25}$ Vibrations or sounds of creations are a crucial component of Bawa's cosmology as they are the language of God in creation. Bawa explains "these are sounds that God has given to each life when it was created" (1976: 114). Bawa evokes them as part of a state (hal) and station (maqam) in which the qalb (heart) hears or learns of the mystery (sirr) of the Truth. God is the ultimate sound and that sound results in a vibration, similar to the process of remembering, that helps lead to the state of insan kamil.

26 Ending the cycle of death and rebirths is an important aspect of Bawa's understandings of the state of insan kamil. Although it is linguistically similar to notions of samsara in the Hindu and Buddhist traditions popular in Sri Lanka, it would appear that he uses the cycle of death and rebirths not to refer to the cycle of a soul's reincarnation through multiple lives, but rather as a metaphor of the soul's inability to return to the divine.

27 In discussing the fundamental essence of the process of creation Bakhtiar explores the different spheres of the macrocosm and microcosm. The macrocosm consists of Hahut (Essential Nature of God), Lahut (Divine Creative Nature), Jabarut (World of Archetypes), Malakut (World of Symbols) and Nasut (human nature). The microcosm contains essence, spirit, heart, soul, and body (13). These two levels of macrocosm and microcosm are interrelated and are dependent on each other, though individually each sphere contains different layers.

${ }^{28}$ His qualities are sometimes referred to as the three thousand qualities of God, see Muhaiyaddeen, Asma'ul-Husna: the 99 Beautiful Names of Allah.
} 
the heart (qalb) which knows God[,] the spirit (ruh) which loves Him[,] and the inmost ground of the soul (sirr) which contemplates Him" (68). When Sufis spoke of the qalb, it was not simply the physical organ that was evoked but the intellectual one as well. Nicholson wrote, "the intellect cannot gain real knowledge of God, [but] the qalb is capable of knowing the essences of all things, and when illumined by faith and knowledge reflects the whole content of the divine mind" (Nicholson, 68). The heart is then figured as the "battlefield on which the armies of God and the Devil contend for victory... [wherein] [t]hrough one gate, the heart receives immediate knowledge of God [and] through another it lets in the illusions of sense" (68).

Bawa explained that the "Light of Iman known as the Light of the heaven of all heavens is there to the night and to the light -Iman must be protected" (1978: 136). He continued: "if one has iman, if one has absolute faith in the right way, and if he understands the Qur'an, then this is the Suratul-Fatihah [Inner Form of Man]. ${ }^{29}$ He will understand what Alhamad [praise] is" (1978: 136). The surat is the body. It has been made with twenty-eight letters. They are the Alhamdu [Heart of Praise]. They are the five Arabic letters of alif, lam, meem [mim], hey [ha] and dal, which Bawa teaches leads to the qalb (Innermost Heart). The twenty-eight letters of the body is the Qur'an and that is the Suratul-Qur'an (the Inner Form of the Qur'an), which is the Suratul-Insan (the Inner Form of Man) (1978: 136). This pure life driven by iman is the manifestation of the human being's return to the beginning of all creation in which the soul was united with the Creator. It is also at this maqam (state) when the qalb, or "heart within the heart," is in the state of Consciousness of Divine Analytic Wisdom where "the Heart and Throne of the True Believer" belongs to Allah that one is in a state of true iman (1976: 198). This inward reality is dependent on the vision of the qalb (heart).

The Qur'an says that it is not the eyes that are blind rather the heart that is (22:46) and so it is the heart that "gives access to the soul, which itself is the gateway to the higher "heart" namely the Spirit and which is referred to as the isthmus (barzakh) that separates the two metaphorical seas of heaven and earth, heart-knowledge and mind-knowledge" (Lings 4852). This vision of heart (ru'yat al-qalb) grants sight to the hidden or unseen certainties of the world (Nicholson 1963). Al-Hallaj stated, "I saw my Lord with the Eye of the Heart" (quoted in Lings 49) and the Prophet taught "consult thy heart, and thou wilt hear the secret ordinance of God proclaimed by the heart's inward knowledge, which is real faith and divinity" (quoted in Nicholson 1963: 53). It is this inward vision of the heart that is at first "blind to celestial glory until the dark obstruction of the phenomenal self with all its sensual contaminations has been wholly cleared away," a process that is completed by God but needs the "in-ward co-operation" of the human being (Nicholson 1963: 70). The knowledge acquired is not that of ordinary knowledge (ilm) but rather of ma'rifat and irfan (gnosis) that "is unification, [and the] realization of the fact that the appearance of 'otherness' beside Oneness is a false and deluding dream" (Nicholson 1963: 70-85). 30

\footnotetext{
${ }^{29}$ For Bawa, Suratul Fatihah or Alhamdu Surah (Inner Form of Man) is composed of 125 letters. The $126^{\text {th }}$ letter is the wisdom or the Light of the Qutbiyat (Consciousness of Divine Analytic Wisdom) and the $127^{\text {th }}$ letter is the Soul. The $128^{\text {th }}$ letter is God and is referred to as "Music" $(1979,173)$. Bawa explains further "within the $128^{\text {th }}$, there is another One. We must look at that power. That is the One that dances without dancing, that sings without singing. That is the One that is love without love. That is music without a form, a music without shape. That is music, which has no colour. It is a very very very wonderful music. So everything is music; we ourselves are music" $(1979,174)$. For Bawa, devotional expressions came in the form of songs, which he sung during discourses, maintain importance in ritual for BMF, which are sung in Tamil but dubbed in English. One can see the importance of his teachings and philosophies expressed through songs mainly in the text Songs of God's Grace (1974). Similar teachings are found in the other texts, i.e., Nur, illusions, angels, prophets, Divine Luminous Wisdom, are found in his songs, but they contain repetition. These songs are not stylistically similar to ode (qasida), lyric (ghazal), quatrain (rabai) or epic (masnavi) (see Ernst 1997). However, it does follow the style of South Asian and Sri Lankan Hindu devotions to the gods/goddesses, in which case it would speak to Bawa's cultural and religious contexts and influences.

${ }^{30}$ Nicholson writes that for Sufis' gnosis and divine love are "spiritually identical; they teach the same truths in different language" and in this regard love and gnosis, "in essence" is a "gift" (1963: 101,112). While Henry Corbin places love in the realm of the ruh, pneuma, or spirit, he explains that the heart is the "center of mystic physiology"
} 
Though achieving the state of the insan kamil is important, Bawa stressed that being in this state was limited to unity with the Divine and a return to a primordial state. Instead he taught that the actualization of the insan kamil expressed the state of perfect being via compassion to all beings. In this state the "heart will melt. If you can study each and every lesson in this way, then your compassion will be there, tears will come, trepidation will come, sorrows will develop. Before the other man realizes his difficulty, it will hurt you" (1978: 12). It is not only the internal state of being that Bawa is concerned with in his teachings; instead, Bawa places significance on the consequence of the external manifestations of the perfect being. The state of the insan kamil demonstrates the Divine Qualities of Allah. It is these Divine Qualities that must be conveyed by the insan kamil within him/herself to God and, most notably, to all creation. As he explains:

within the awareness of other lives existing as one's own life is the Clarity of Wisdom and within that Clarity is the Light of God within that Light is the Soul and within that Soul, the Kingdom of God exists which is complete Beautiful Effulgence and within that lies the Commandments of God and within that is Heaven, where the Light of Man exists and this Light is True Peace. (1976: 75)

Allah reveres this heart of the perfect being. In a hadith tradition emphasized by Bawa he explains:

If anybody hurts the heart of the one who is an insan kamil (one who is a slave to Allah, one who is a mu'min or a true believer), Allah cannot bear it. Whether learned people or ordinary people hurt the heart of such a son, Allah cannot bear it or grant forgiveness. If you ask forgiveness from Allah in that instance, He will say, 'ask forgiveness from the one you have hurt.' In that instance, you will have to ask forgiveness from the slave of God. As soon as his qalb is made peaceful, and Allah's love will be peaceful ... [but] the punishment for hurting a slave of God will come to you immediately; it is like falling into a fire. That is the meaning of this hadisz [sic]. (1979: 5)

The above tradition emphasizes the importance and reverence of the heart, or the qalb, by God. Chittick explains "the heart is the human faculty that can embrace God in the fullness of his manifestation" and Ibn "Arabi explained that "the heart alone can know God" (15). In Bawa's "Change to Insan Kamil the Direct Connection" it was this aspect of the qalb that he felt that humanity neglected. Bawa understood that in the past, humanity was not concerned with the beautification of outer form or obsessed with material gain. Instead the human being, the insan, beautified his/her qalb so that the heart had a strong bond and relationship with Allah and remained united with all His qualities. For Bawa the perfect being embodies the compassion of Allah or Andavan (T) (God) to all creation, regardless of religious creed, race, gender or any other forms of division. Still, the perfect being represents Islam- which ultimately for Bawa was understood in the embodiment of anbu (T) or ishk (love) of the inner heart. This anbu is to be personified in actions towards fellow human beings. Ultimately, then, the insan kamil's honoured position both between God and His creation is due to the Reality of his Being, a Reality that is the Ultimate Reality itself and dependent on being in the world. When this potential is reached one becomes the microcosm (small world) of the macrocosm (universe).

(quoted in Chittick 2007: 200). He explains: "the power of the heart is a secret force or energy, which perceives divine realities by a pure hierophanic knowledge without mixture of any kind, because the heart contains even the Divine Rahma. In its unveiled state, the heart of the gnostic is like a mirror which the microcosmic form of the Divine Being is reflected" (Ibid.). 


\section{Conclusion}

Using Sufi hermeneutical thought, I have read Bawa's teaching through the frames of classical Sufi thinkers and teachers but this paper represents a brief exploration with limitations that are suggestive of future research endeavours. When I began the study, I oriented insan kamil within classical traditions of South Asian and Persian metaphysicians who have contributed extensively to the study of the perfected being. And although the development of the insan kamil from al-Jili to Bawa has not been completed such a study would be immensely fruitful to draw contrasts to the issue of insan kamil in the discussions of classical Sufi thought and that of Bawa as his discourses on insan kamil illuminate similar themes, albeit in differing cultural and historical contexts. Such a study would also present an opportunity to understand the metaphysical topography by mapping the transnational linkages between North American, South Asian (Sri Lankan) and Middle Eastern Sufi traditions. It is clear that Bawa's discourses are steeped within the Qur'anic tradition, especially in terms of the references to prophets and angels, but Bawa's discussion of the nabimurgal [sic] (prophetic people) for example, is nuanced differently from the traditional stories as in the case with the discussion of Khidr in the Guidebook. Bawa also does not seem to cite from any particular hadith traditions or schools of law even though the Fellowship masjid (mosque) established in Philadelphia follows traditional Hanafi-madhab (school) and is associated with the Qadiri Sufi lineage. Instead he is engaging in ta'wil, or the inner interpretations, of these Islamic texts in an oral tradition, perhaps uniquely Tamil-Islamic, developed in Sri Lanka. For instance, one sees a synthesis of Hindu traditions, South Asian cultural norms and Tamil merged with Arabic and Sanskrit languages as well as North American cultural practices and norms i.e., references to films and television shows, such as Kung Fu. Exploration of the teachings by Bawa suggests a Tamil-Islamic Sufi orientation with universalistic and inclusive teachings but further study is required to probe these interpretations. These potential projects are important as they would aid to broaden ongoing discussions of Sufi traditions in North America as well as help develop a lexicon that highlights the linguistic and mystical features of Arabic, Tamil and Sanskrit that have been evident in Bawa's repertoire. The shared themes of Hindu cosmology and Islamic theology in Bawa's teachings also require further treatment perhaps by those with specialist training in Hindu cosmology and cosmography to provide a more nuanced analysis of Bawa's teachings within Hindu and tantric frameworks. Not only would this contribute to the deeper analysis of Bawa's teachings, it would highlight the historical sharing of Hindu and Islamic mystical traditions in Sri Lanka, an arena in which cosmological and metaphysical studies of IslamicSufism is desperately in need of attention. Finally, such studies on the discourses of Bawa would present new perspectives for understanding embodied and lived realities of the teachings of Bawa amongst his various followers who range from Muslim-Sufis, Sufis, universalists and perennial thinkers and who come from diverse ethnicities of South Asian, North American, East African and Middle Eastern adherents that form the modern and transnational reality of global Sufism (Beyer 2008; Hermansen 2008). If the metaphysical and cosmological teachings of Bawa on insan kamil illuminate the intersections of different boundaries of religious, cosmological, theological and metaphysical realms and layers, then it could serve as a critical tool for social scientists and religious studies scholars who are trying to grapple with the lived appeal, diversity and eclecticism of Muhammad Raheem Bawa Muhaiyaddeen in contemporary Sufism in North America, South Asia and beyond.

\section{References}

Arberry, A. J. 1950. Sufism an Account of the Mystics of Islam. London: George Allen \& Unwin.

Bakhtiar, Laleh. 1976. Sufi Expressions of the Mystic Quest. New York: Thames and Hudson. Buckhardt, Titus. 1976. Introduction to Sufism. London: Thorsns. 
Chittick, W. C. 2000. Sufism: A Beginner's Guide. Oxford: Oneworld Books.

Chittick, W. C. 2005. Ibn 'Arabi . Oxford : Oneworld Publications.

Izutsu, T. 1983. Sufism and Taoism A Comparative Study of Key Philosophical Concepts. California: University of California Press.

Korom, F. J. 2012. "The Presence of Absence: Using Stuff in a South Asian Sufi Movement." AAS Working Papers in Social Anthropology: 1-19.

Korom,F. 2012b. “Speaking with Sufis: Dialogue With Whom and About What?" In C. Cornille \& S. Corigliano (eds.). Interreligious Dialogue and the Cultural Shaping of Religions. Egene: 224-249. Oregon: Cascade Books.

Korom, F. 2011. "Charisma and Community: A Brief History of the Bawa Muhaiyaddeen Fellowship." The Sri Lanka Journal of the Humanities 37/1-2: 19-33.

Lings, Martin. 1975. What is Sufism? Berkeley: University of California Press.

Massignon, Louis. 1982. The Passion of al-Hallaj: Mystic and Martyr of Islam: the teachings of alHallaj, Vol 3. (Herbert Mason trans). Princeton: Princeton University press.

Muhaiyaddeen, B. 1976. The Guidebook to the True Secret of the Heart (Vol. 2). Philadelphia: Fellowship Press.

Muhaiyaddeen. B. 1978. God His Prophets and His Children. Philadelphia: Fellowship Press.

Muhaiyadeen, Bawa. 1978b. "Come Together and Search for God." Philadelphia: Fellowship Press. MP3

Muhaiyaddeen, B. 1979. Asma'ul Husna The 99 Beautiful Names of Allah. Philadelphia: Fellowship Press.

Muhaiyadeen, Bawa. 1979b. "Change to Insan Kamil: the Direct Connection." Philadelphia: Fellowship Press. MP3.

Muhaiyaddeen, B. 2003. The Tree that Fell to the West: Autobiography of a Sufi. Philadelphia: Fellowship Press.

Muhaiyaddeen, B. 2006. The Map of the Journey to God Lessons from the School of Grace. Philadelphia: Fellowship Press.

Nicholson, Reynold. 1963. The Mystics of Islam. London: Routledge and Kegan Paul.

Schimmel, Annemarie. 1992. Islam: An Introduction. New York: State University of New York Press.

Shah Waliuallah of Delhi. 1982. the Sacred Knowledge of Higher Functions of the Mind.(C.G. Jalbani trans.). London: the Octagon Press.

Webb, Gisela. 2006. “Third-Wave Sufism in America and the Bawa Muhaiyaddeen Fellowship" in Jamal Malik and John Hinnel (eds.). Sufism in the West: 86-102. New York : Routledge.

Webb, Gisela. 1998. “Teaching with Pictures: Three Paintings of Bawa Muhaiyaddeen” in Renard, J. (ed).Windows on the House of Islam: 290-296. Berkeley: University of California Press.

Merin Shobhana Xavier, Laurier-Waterloo University, Canada 